
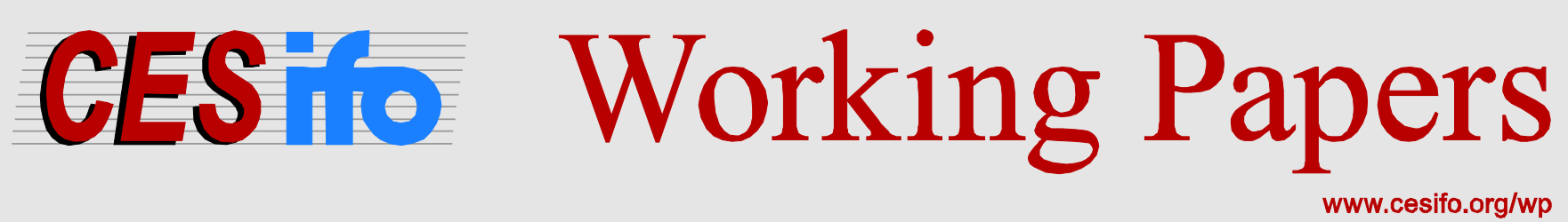

\title{
Innovation in the Supply and Procurement of Rig Services
}

\author{
Petter Osmundsen
}

CESIFO WORKING PAPER NO. 4961

CATEGORY 11: INDUSTRIAL ORGANISATION

SEPTEMBER 2014

An electronic version of the paper may be downloaded

- from the SSRN website:

- from the RePEc website:

www.SSRN.com

- from the CESifo website:

www.RePEc.org

www.CESifo-group.org/wp

\section{CESifo}




\title{
Innovation in the Supply and Procurement of Rig Services
}

\begin{abstract}
Substantial elements of innovation have been observable during recent years in rig supply, in particular regarding contracts and organisation. This trend has been driven by the fact that rising costs over many years have put profitability under pressure. On the basis of theory and available empirical insights, the paper outlines the conditions where specific organisational and contractual solutions are best suited. Optimum rig procurement will depend in part on whether the oil companies have time-critical drilling targets, the ability and willingness of the parties to bear risk and the purchaser's competence and capacity to manage and follow up procurement.
\end{abstract}

JEL-Code: L600, G340, M100.

Keywords: rig services, contracts, organization, innovation.

Petter Osmundsen

Department of Industrial Economics

and Risk Management

University of Stavanger

Norway-4036 Stavanger

Petter.Osmundsen@uis.no

August 2014

Thanks are due to a number of specialists in petroleum-related government agencies, the oil industry and the supplies sector for useful suggestions and comments. Thanks to the Research Council of Norway for funding. 


\section{Introduction}

Despite high oil prices, oil companies struggle to develop new projects. This is due to rising costs, chief of which are drilling costs. The paper analyses new approaches by oil companies to curb drilling costs. In an effort to reduce rig rates, the oil companies are investigating whether new ways of organising the relationship between themselves and the rig contractors including changes to risk-sharing and ownership - can increase the supply of units at acceptable cost. The scarcity of rigs, combined with a considerable lengthening in contract durations, has led to a number of interesting examples of innovation in contractual and organisational patterns for drilling. These include new types of incentives in drilling contracts, small oil companies joining forces to establish a rig consortium, and vertical integration where oil companies own rigs.

Examples and cases presented in the paper are taken from the Norwegian Continental Shelf (NCS). Since all petroleum provinces have experienced rising rig rates, since major players in both among oil companies, rig companies and oil services are present on the NCS, and since the contracts for rig hire mostly follow an international standard, the findings in the paper are likely to have global relevance.

A distinction can be made between fixed and mobile drilling units. This paper addresses mobile units or rigs. Licences have normally always owned the drilling units permanently installed on platforms. Crews are hired from drilling contractors, and maintenance is usually also contracted out. The mobile rigs operating on the NCS have been owned by a rig contractor and chartered in to conduct drilling operations. ${ }^{2}$

The paper builds on general economic incentive and contract theory, and on more specific research in the drilling field, such as Corts (2000) and Osmundsen et al (2006, 2008). See the list of references. In addition, I have had a series of meetings and conversations with specialists closely involved with decisions related to rig procurement, including technical and organisational conditions, legal aspects and taxation. I have also had access to rig contracts used on the NCS.

\footnotetext{
${ }^{2}$ Such units can be divided into two main categories - jack-ups standing on the seabed and semi-submersible floaters. Drill ships also exist, but only one of these is found on the NCS.
} 
It should be noted that the subject is complex, with no clear and simple answers to the issues involved. A multitude of different company and contractual structures exist for rigs, production ships and so forth worldwide, depending on tax regime, ownership systems in licences, market conditions and so forth. Theoretically, players often weigh up different considerations when choosing contractual and organisational solutions. Empirically, successful companies applying different solutions can be found side by side in a sector. And a correspondingly wide array of approaches to rig procurement exists internationally. A number of interesting general insights of a conditional nature can nevertheless be found. On the basis of theory and available empirical considerations, something can be said about the conditions where specific organisational and contractual solutions are best suited.

\section{New type of rig contractor}

The NCS has been developed by big oil companies, and contractual templates are tailored accordingly. New companies have other requirements, including for risk-sharing. In drilling, the oil companies bear the main oil-price, foreign-exchange and production risk. The issue of contracts where the contractor bears a larger share of the risk is making itself felt in Norway through the establishment of new and often smaller oil companies. These lack the same ability to carry financial risk as existing companies on the NCS, and depend on sharing risk with their contractors. In exchange, the latter get to share in the upside of the projects.

Aker Exploration company was created to aim at the need for greater contractual diversity. It offered rigs for exploration drilling on the NCS. In exchange for bearing the whole drilling cost, Aker Exploration obtained a share of the oil or gas field in the event of a discovery. ${ }^{3}$ This represents vertical integration - an enterprise which is both an oil company and a provider of rig services - and is an interesting innovation on the NCS. In addition to securing sorely needed rigs tailored for Norwegian requirements, it represents a contractual novelty which reduces cost and risk for the oil company. This should be particularly suited for new players on the NCS.

Compared with traditional rig contractors, however, this model makes bigger demands on the ability to bear risk and breadth of expertise - which must also embrace energy markets and reservoir conditions. The challenge is to avoid the problem of adverse selection, or a position

\footnotetext{
${ }^{3}$ Stavanger Aftenblad, 12 April 2006.
} 
where oil companies exploit their better reservoir knowledge (asymmetric information) to offer co-ownership only for the least attractive acreage and to tackle the other blocks on their own account. However, adverse selection is a general problem for companies seeking to farm into oil fields. Another problem involves overcoming challenges related to a second-hand market for licences on the NCS which at times can be illiquid. The big companies on the NCS have traditionally demonstrated little interest in farming out of licences. On the basis of ambitious production and reserve goals, they have often been keener to swap licence holdings than to sell them. Exchanging rig capacity for a licence interest could therefore prove a demanding issue, since Aker's business model here depends on convincing all participants in the relevant licences. This normally involves time- and resource-intensive negotiations. With good help from a tight rig market, however, the company has succeeded in securing deals. Aker Exploration entered, for example, into an agreement on taking over 30 per cent of ENI's sole holding in production licence (PL) 259 in exchange for providing the Aker Barents rig. Aker Exploration also acquired ENI’s 55 per cent interest in PL 256. ${ }^{4}$ Aker Exploration merged in 2009 with Det Norske to become Det Norske Oljeselskap. ${ }^{5}$

Linking licence transactions with rig provision would represent a socio-economic benefit if it increased the liquidity of the licence market. Generally speaking, this liquidity appears to have increased on the NCS, and Aker Exploration's timing was good. One challenge would have been that liquidity varies over time, which was perhaps one reason for the merger. The combination of rig and own licence interests seems more flexible, since the need to swap rig provision with licence interests has declined. It also opens to some extent for licence swaps.

Swapping licence interests for drilling capacity represents a further development of "farm in/farm out” arrangements. Such arrangements could be prompted by a lack of rig capacity or budgetary constraints on exploration funding at the oil company doing the farm-out. This operation is particularly relevant for new entrants on the NCS which have not built up their own production. Farm in/farm out deals have previously been agreed between the oil companies. Aker Exploration and Aker Drilling are examples of a combined solution for rig contractor and oil company using shared equity interests to implement such arrangements. Certain other rig contractors internationally also offer solutions of this kind. These require the

\footnotetext{
${ }^{4}$ http://www.dn.no/energi/article1204240.ece

5 http://e24.no/makro-og-politikk/det-norske-og-aker-exploration-fusjonerer/3232536
} 
contractor to expand its expertise base beyond rig operation, and to acquire knowledge of reservoirs in order to deal with the new risks and opportunities it faces.

A relevant question is whether the examples of vertical integration, where an oil company secures a rig or a contractor seeks licence interests, is driven primarily by short-term economic conditions or whether they represent a sustainable and fundamental business strategy. The current shortage of rigs is driving special solutions. In addition, very high rates make rig ownership tempting for oil companies as a supplementary business activity. However, it remains to be seen whether these types of strategies survive an economic downturn with a buyer's market for rig services. Oil companies presumably do not normally own rigs for a reason. Several hazards exist. Risk is high, since it cannot normally be spread to the same extent achieved by big international oil companies through part-ownership of many different licences. Small oil companies lose flexibility by owning rig capacity, and it is very uncertain whether they have the financial muscle to retain such ownership over time. However, risk exposure will be affected by the contracts employed, and new solutions are also conceivable here. If rig slots can be sold in many fields with different geological structures, technical portfolio diversification will be achieved. The precondition then is that the activity can achieve a certain scale and spread. Another common objection to oil companies owning rigs is that this does not form part of their strategic core (focusing strategy) - one cannot be good at everything. Over time, moreover, an oil company’s own rig fleet would not normally match its licence portfolio, and it could quickly end up in the position of providing a rig as a contractor to customers it competes with as an oil company. An international player will face geographical mismatches, and moving rigs is expensive. An oil company will also normally have varying demand for rigs. The big international players do not normally want to sit with continuous rig exposure through ownership when their drilling requirements vary sharply both over time and in geographical spread. Overall, therefore, many considerations argue for outsourcing here. The exception could be conditions where a long-term drilling requirement with a specific type of rig is seen.

\section{New contracts}

Rig contractors and oil service companies must be urged to formulate contracts suitable for new small players on the NCS. These would need to involve a different sharing of risk compared with current contracts. The latter are influenced by the fact that players on the NCS 
have been large international companies, with a substantial ability to bear risk and a high level of expertise in the management of drilling operations. Things are different for a number of new entrants on the NCS. They will want to shift more risk to their contractors, and depend much more on purchasing external expertise. To meet this demand, contractors must extend their expertise base and develop suitable systems for risk management. However, risk exposure must be carefully reconciled at all times with the contractors' ability to bear risk. Research from the Gulf of Mexico shows that turnkey contracts are primarily used for exploration wells drilled from jack-ups in shallow water, and that the companies using such contracts are small players with limited experience and financial strength (Corts, 2000). Exploration wells in the North Sea for some of the new companies on the NCS should fit that description. Well intervention is another possible example. However, establishing such contracts requires drilling contractors willing to bear the increased risk and to expand their scope of activity and range of services. That seems to be case for only a limited number of existing contractors. A clear distinction exists, for example, between drilling contractors and oil service companies, and none appear particularly willing to bear reservoir and oil price risk.

Intermediate solutions are possible - not a single turnkey contractor for drilling, but at least fewer suppliers because more drilling services are delivered by the same oil service firm. That simplifies procurement and management processes for the oil company. It also permits wider use of incentive agreements because a contractor delivering more services gains better control of the drilling process. The collaboration between Pertra and Halliburton indicates that new procurement models of this type could boost value added. A trend towards coordinated deliveries should also be interesting for international oil companies, since the benefits - more coordination and reduced transaction costs - seem comparable with the coordination on the contractor side seen in development projects with the introduction of engineering, procurement, construction and installation (EPCI) contracts. However, the advantages of greater coordination by contractors must be weighed against the drawbacks of reduced competition - in practice, few companies can offer such a broad range of services - and less specialisation.

Cost increases in the oil industry are a significant problem. Decentralised contract structures in this area can mean sub-optimisation. While very strong incentives (competitive rates) can be optimum at project level, they can drive up offshore costs as a whole. Thus, seen from the perspective of government the welfare effects of new contract forms have to be weighed up, with the possible efficiency benefits of stronger incentives balanced against a rise in costs. 
While big oil companies will internalise much of the cost growth at the overall continentalshelf level, and thereby have virtually the same interests as the government, those with a small portfolio on the NCS will by and large give emphasis to incentive considerations. The supplementary incentives in oil service contracts are reportedly profitable for the individual licence. When evaluating profitability at the continental-shelf level, however, possible contagious effects in the form of increased rates in competing licences must be taken into account. But the supplementary incentives represent such small amounts that they are not a significant problem. Moreover, innovative thinking should be welcomed in a contract area which has been very conservative.

\section{New oil companies - rig consortium}

New companies on the NCS are particularly affected by the rig shortage. It may be more difficult for them to gain access to rigs, since the rig contractors primarily want to deal with big customers who place large, long-term charters. This can create problems for newcomers in fulfilling government-imposed drilling commitments specified in work programmes. On top of that, of course, come the expectations and demands of impatient shareholders.

Seven small companies have joined forces to charter a rig through a consortium led by DPT (now AGR). These players are largely located on the same site, the Veritas building in Stavanger. That has permitted the creation of a joint safety centre for drilling operations, which is operated on a "shift" system by the company using the rig at any given time. In other words, the benefits of scale and shared location accrue here to the operator. The new players have otherwise gone further than the big companies in outsourcing rig management. Another player in the rig consortium field is Rig Management Norway. As I understand it, feedback on these consortia has been good.

Small oil companies want to share risk differently with their contractors and to use other contract formats - with the contractor bearing a number of consequential costs in the event of downtime, for example, or sharing the production and oil price risk. An obstacle here is that contractors normally lack the ability or willingness to accept this type of risk. Their defence is that the new companies are not prepared to pay for all the responsibility they want to transfer. Cases exist from the UK where this type of risk transfer to the contractors led to renegotiation of the contract - the contractor was unable to bear the risk. Similar experiences have been 
made in development projects on the NCS. The lesson is that incorporating more risk than the contractor can bear would not be appropriate. With some exceptions, contractors basically do not want contracts linked to production volumes or sales, since they are not willing to accept reservoir or price risk. On smaller fields, however, it could be the case that contractors are better suited to bearing this type of risk than newly established oil companies.

One implication of the lack of ability and willingness to bear risk in the contractor chain is that not all oil companies are suited for pursuing major field developments. In a number of cases, it would be preferable to sell interests to companies with sufficient ability to execute the project. Developments on the NCS often demand a lot from the operator's organisation in the form of expertise and capacity. A number of jobs in such areas as project follow-up are not appropriate for outsourcing. They form part of the strategic core in the oil companies. Furthermore, such projects make big demands on the capital adequacy and liquidity of the licensees - cost overruns and delays can be difficult to cope with for new players. However, it is probably only a matter of time before a market for bearing risk develops in the contractor sector in order to meet this new demand.

\section{New rig types}

Statoil has moved from a position where it stopped the chartering process for rigs in 2008 to a more active procurement approach which includes the design of new rig categories and assessing rig ownership. An enquiry for chartering a rig had been issued by StatoilHydro in the summer of 2008, covering both semi-submersibles and jack-ups and starting in $2012 .^{6}$ The company requested updated bids from contractors and secured a reduction in the rates offered. It nevertheless decided to terminate the process because the rates were considered to be too high.

In collaboration with international contractors, Statoil has developed completely new rig concepts for use in improved recovery and on new fields. ${ }^{7}$ In May 2011, it awarded a contract to Songa Offshore for two new Category D units to be used on the NCS. A total of four such rigs have been ordered by the company from Songa. The goal is that the new type will do the work 20 per cent more efficiently than conventional rigs. Challenges have arisen in relation to

\footnotetext{
${ }_{7}^{6}$ http://www.statoil.com/no/NewsAndMedia/News/2008/Pages/22DecRig.aspx

7 http://www.statoil.com/no/TechnologyInnovation/TechnologyManagement/Pages/Statoils\%20riggstrategi.aspx
} 
Songa's capital adequacy, and problems with yards and delays have been reported. ${ }^{8}$ Norwegian business daily Dagens Næringsliv reported on 26 November 2013 (pp 6 and 7) that "Statoil is the biggest contributor to what is intended to be the final rescue of financially distressed Songa Offshore”. Statoil, creditors and owners are helping to save the company from liquidation. According to the paper, Statoil's contribution takes the form of raising rates for the four rigs by USD 300 million in all. USD 100 million will be repaid if it exercises all eight options for lengthening the four rigs.

Statoil entered in April 2012 into a contract with Aker Solutions for a new Category B rig concept. This unit is designed to conduct various types of well interventions with wirelining and coiled tubing, and for through tubing rotary drilling (TTRD) of sidetracks. Aker Solution's share price reacted negatively to the signing, since income was fixed while costs were uncertain. The parties agreed in June 2013 to cancel the charter for the new rig category. ${ }^{9}$ As I understand it, disagreement had arisen over sharing the cost of maturing the new concept. Each of the parties was to cover its own expenses.

\section{Conclusion}

Substantial elements of innovation have been observable during recent years in rig supply and organisation on the NCS. This trend has been driven partly by the fact that rising costs over many years have put profitability under pressure, and partly by the entry of new oil companies on the NCS with different needs from the large established players.

Innovation has occurred along several dimensions. One is technical innovation, with the development of new and more specialised rig types. The idea is that units should be more cost-effective and productive when they are purpose-designed for more specialist tasks. New rig categories have encountered short-term resistance from contractors, but will probably play a key role in a future Norwegian rig market. It will be easier to establish specialised rigs when the market is less tight. Much innovation has also occurred with contracts and organisation. Examples include changes to risk-sharing in contracts and vertical integration.

\footnotetext{
${ }^{8} \mathrm{http}: / / \mathrm{www} . \mathrm{dn} . n o /$ energi/article2670029.ece

9 http://www.statoil.com/no/NewsAndMedia/News/2013/Pages/24Jun_CatB.aspx
} 
Some of these changes might be determined to a certain extent by economic conditions. One example could be oil companies owning rigs. Other innovations will represent lasting adjustments to collaborative relations between oil companies and contractors. New oil companies are less keen than the established players to build up large internal staffs to supervise drilling operations. This will mean a trend towards contractors taking on more functions than has been usual on the NCS. A greater use of turnkey contracts and integration of services can be seen. That makes big demands on the breadth of contractor knowledge, and calls for greater willingness and ability to bear risk. This is likely to create a number of challenges in a transitional phase.

\section{References}

Corts, K, 2000, “Turnkey Contracts as a Response to Incentive Problems: Evidence from the Offshore Drilling Industry”, working paper, Harvard University.

Corts, K S, and Singh, J (2004), “The Effect of Repeated Interaction on Contract Choice: Evidence from Offshore Drilling”, Journal of Law, Economics, and Organization 20 (1), 2004, 230-260.

Hart, O (1995), Firms, Contract, and Financial Structure, University Press.

Hillier, B, 1997, The Economics of Asymmetric Information, Macmillan Press Ltd, London.

Milgrom, P and Roberts, J (1992), Economics, Organization, and Management, Prentice Hall, Englewood Cliffs, NJ.

Moen, G K (2013), “1000+ wells to get 50\% + recovery!”, presentation on business opportunities and challenges in mature fields, Norwegian Petroleum Society, Stavanger, 1617 April 2013.

Moomjian, C A (1999), "Contractual insurance and risk allocation in the offshore drilling industry”, Drilling Contractor, January/February, 19-21.

Osmundsen, P (2013), “Choice of Development Concept - Platform or Subsea Solution? Implications for the Recovery Factor”, Oil \& Gas Facilities (SPE), October, 64-70.

Osmundsen, P (2010), “Chasing Reserves - Incentives and Ownership”, in Bjørndal E, Bjørndal, M, Pardalos, P M, and Rönnqvist, M, eds (2010), Energy, Natural Resource and Environmental Economics, Springer-Verlag Berlin Heidelberg, ISSN 1867-8998; ISBN 9783-642-12066-4, 19-39.

Osmundsen, P, Rosendahl, K E and Skjerpen, T (2013), “Contract Structure and Rig Rates”, IAEE European Conference 2013, Dusseldorf, 18-21 August 2013. 
Osmundsen, P, Skjerpen, T and Rosendahl, K E (2012), “Understanding rig rates”, proceedings, International Association for Energy Economics (IAEE), Venice, 9-12 September 2012.

Osmundsen, P, Sørenes, T and Toft, A (2008), “Drilling Contracts and Incentives”, Energy Policy 36, 8, 3138-3144.

Osmundsen, P, Sørenes, T and Toft, A (2010), “Offshore Oil Service Contracts - New Incentive Schemes to Promote Drilling Efficiency”, Journal of Petroleum Science and Engineering 72, 220-228.

Osmundsen, Asche, Misund and Mohn (2006), "Valuation of International Oil Companies”, Energy Journal, 27, 3, 49-64.

Osmundsen, P, Mohn, K, Asche, F and Misund, B (2007), "Is the Oil Supply Choked by Financial Markets?”, Energy Policy 35, 1, 467-474.

Osmundsen, P, Roll, K and Tveterås, R (2010), "Exploration Drilling Productivity at the Norwegian Shelf”, Journal of Petroleum Science and Engineering, 73, 122-128.

Osmundsen, P, Roll, K H and Tveterås, R (2012), "Drilling speed - the relevance of experience”, Energy Economics 34, 786-794.

Osmundsen, P, Sørenes, T and Toft, A (2008), “Drilling Contracts and Incentives”, Energy Policy 36, 8, 3138-3144.

Osmundsen, P, Aven, T and Vinnem, J E (2008), "Safety, Economic Incentives and Insurance”, Reliability Engineering \& System Safety 93, 1, 137-143.

Osmundsen, P, Toft, A and Dragvik, K A (2006), “Design of Drilling Contracts - Economic Incentives and Safety Issues”, Energy Policy 34, 2324-2329

Rig Commission (2012), Økt bore- og brønnaktivitet på norsk sokkel, report from an expert commission appointed by the Ministry of Petroleum and Energy, 19 December 2011.

Published Thursday 16 August 2012:

http://www.regjeringen.no/upload/OED/pdf\%20filer/bore_og_br_aktivitet_riggutvalget_2012. pdf.

Improved Recovery Commission (2010), Økt utvinning på norsk Kontinentalsokkel, report from an expert commission appointed by the Ministry of Petroleum and Energy, published 22 September 2010, chaired by Knut Åm: http://www.regjeringen.no/nb/dep/oed/dok/rapporter/2010/Okt-utvinning-pa-norskkontinentalsokkel.html?id=615841. 